\title{
Postmaterialism Influencing Total Entrepreneurial Activity across Nations
}

\author{
Lorraine Uhlaner and Roy Thurik
}

\begin{tabular}{|l|l|}
\hline \multicolumn{2}{|l|}{ ERIM REPORT SERIES RESEARCH IN MANAGEMENT } \\
\hline ERIM Report Series reference number & ERS-2006-062-ORG \\
\hline Publication & November 2006 \\
\hline Number of pages & 20 \\
\hline Persistent paper URL & \\
\hline Email address corresponding author & uhlaner@few.eur.nl \\
\hline Address & Erasmus Research Institute of Management (ERIM) \\
& RSM Erasmus University / Erasmus School of Economics \\
& Erasmus Universiteit Rotterdam \\
& P.O.Box 1738 \\
& 3000 DR Rotterdam, The Netherlands \\
& Phone: $\quad+31104081182$ \\
& Fax: $\quad+31104089640$ \\
& Email: info@erim.eur.nl \\
& Internet: $\quad$ www.erim.eur.nl \\
\hline
\end{tabular}

Bibliographic data and classifications of all the ERIM reports are also available on the ERIM website: www.erim.eur.nl 


\section{ERASMUS RESEARCH INSTITUTE OF MANAGEMENT}

\section{REPORT SERIES \\ RESEARCH IN MANAGEMENT}

\begin{tabular}{|c|c|}
\hline \multicolumn{2}{|c|}{ ABSTRACT AND KEYWORDS } \\
\hline Abstract & $\begin{array}{l}\text { The relative stability of differences in entrepreneurial activity across countries suggests that } \\
\text { other than economic factors are at play. The objective of this paper is to explore how } \\
\text { postmaterialism may explain these differences. A distinction is made between nascent } \\
\text { entrepreneurship, new business formation and a combination of the two, referred to as total } \\
\text { entrepreneurial activity, as defined within the Global Entrepreneurship Monitor (GEM). The } \\
\text { model is also tested for the rate of established businesses. The measure for postmaterialism is } \\
\text { based upon Inglehart's four-item postmaterialism index. A set of economic, demographic and } \\
\text { social factors is included to investigate the independent role postmaterialism plays in predicting } \\
\text { entrepreneurial activity levels. In particular, per capita income is used to control for economic } \\
\text { effects. Education rates at both secondary and tertiary levels are used as demographic } \\
\text { variables. Finally, life satisfaction is included to control for social effects. Data from } 27 \text { countries } \\
\text { (GEM, World Values Survey and other sources) are used to test the hypotheses. Findings } \\
\text { confirm the significance of postmaterialism in predicting total entrepreneurial activity and more } \\
\text { particularly, new business formation rates. }\end{array}$ \\
\hline Free Keywords & $\begin{array}{l}\text { Comparative Analysis of Economies, Cultural Economics, Entrepreneurship, Self-employment, } \\
\text { Macro-economic Analyses of Economic Development }\end{array}$ \\
\hline Availability & $\begin{array}{l}\text { The ERIM Report Series is distributed through the following platforms: } \\
\text { Academic Repository at Erasmus University (DEAR), DEAR ERIM Series Portal } \\
\text { Social Science Research Network (SSRN), SSRN ERIM Series Webpage } \\
\text { Research Papers in Economics (REPEC), REPEC ERIM Series Webpage }\end{array}$ \\
\hline Classifications & $\begin{array}{l}\text { The electronic versions of the papers in the ERIM report Series contain bibliographic metadata } \\
\text { by the following classification systems: } \\
\text { Library of Congress Classification, (LCC) LCC Webpage } \\
\text { Journal of Economic Literature, (JEL), JEL Webpage } \\
\text { ACM Computing Classification System CCS Webpage } \\
\text { Inspec Classification scheme (ICS), ICS Webpage }\end{array}$ \\
\hline
\end{tabular}




\title{
Postmaterialism Influencing Total Entrepreneurial Activity across Nations
}

\section{Lorraine Uhlaner}

European Family Business Institute, Centre for Advanced Small Business Economics, Erasmus School of Economics and Business Economics, Erasmus University Rotterdam, P.O. Box 1738, 3000 DR Rotterdam, the Netherlands and EIM Business and Policy Research, P.O. Box 7001, 2701 AA Zoetermeer, the Netherlands, uhlaner@few.eur.nl

\section{Roy Thurik \\ Centre for Advanced Small Business Economics, Erasmus School of Economics and Business Economics, Erasmus University Rotterdam, P.O. Box 1738, 3000 DR Rotterdam, the Netherlands, EIM Business and Policy Research, P.O. Box 7001, 2701 AA Zoetermeer, the Netherlands and Max Planck Institute of Economics, Jena, Germany, thurik@few.eur.nl}

\begin{abstract}
The relative stability of differences in entrepreneurial activity across countries suggests that other than economic factors are at play. The objective of this paper is to explore how postmaterialism may explain these differences. A distinction is made between nascent entrepreneurship, new business formation and a combination of the two, referred to as total entrepreneurial activity, as defined within the Global Entrepreneurship Monitor (GEM). The model is also tested for the rate of established businesses. The measure for postmaterialism is based upon Inglehart's four-item postmaterialism index. A set of economic, demographic and social factors is included to investigate the independent role postmaterialism plays in predicting entrepreneurial activity levels. In particular, per capita income is used to control for economic effects. Education rates at both secondary and tertiary levels are used as demographic variables. Finally, life satisfaction is included to control for social effects. Data from 27 countries (GEM, World Values Survey and other sources) are used to test the hypotheses. Findings confirm the significance of postmaterialism in predicting total entrepreneurial activity and more particularly, new business formation rates.
\end{abstract}

Keywords comparative analysis of economies, cultural economics, entrepreneurship, self-employment, macroeconomic analyses of economic development

JEL codes L26, P52, Z1, M13, O11, O57

Version November 17, 2006 17(2), 2007

An update is accepted for publication in Journal of Evolutionary Economics

Acknowledgement We would like to thank Peter van Hoesel, André van Stel, Ingrid Verheul and Sander Wennekers for helpful comments. We would also like to thank Jan Hutjes, Jacques Niehof and Hanneke van de Berg for their contributions to earlier versions of this paper. Earlier versions have been read at the Small Business and Entrepreneurship Development Conference (University of Nottingham, UK, 15-16 April 2002), the Babson Kauffman Entrepreneurship Research Conference (University of Colorado, Boulder, Co, 6-8 June 2002), ICSB 47th World Conference (San Juan, Puerto Rico, 15-19 June 2002) the BRIDGE Annual Entrepreneurship Workshop (Bloomington, In, 21 April 2003), the Global Entrepreneurship Research Conference I, Berlin (KfW bank), 1-3 April 2004 and the Workshop on Entrepreneurship and Culture (Max Planck Institute of Economics, Jena, 7 Februari 2005). The present report has been written in the framework of the research program SCALES which is carried out by EIM and financed by the Dutch Ministry of Economic Affairs. Lorraine Uhlaner acknowledges financial support of Arenthals Grant Thornton Netherlands, Fortis Bank, and Fortis MeesPierson, a subsidiary of Fortis Bank specialized in private wealth management.

Document Post-materialism-Uhlaner-Thurik-erim.doc 


\section{Introduction}

The objective of this paper is to explore whether postmaterialism explains differences in Total entrepreneurial activity rates across countries. First coined by Inglehart (Abramson and Inglehart, 1999; Inglehart, 1977; Inglehart, 1990; Inglehart, 1992; Inglehart, 1997; Inglehart, 2000), postmaterialism describes the degree to which a society places immaterial life-goals such as personal development and self-esteem above material security. Total entrepreneurial activity is defined as the share of adults in the total population of 18 to 64 years old, who are either actively involved in starting a new business (nascent entrepreneurship) or in managing a business less than 42 months old (new business formation) (Reynolds, Camp, Bygrave, Autio and Hay, 2001; Reynolds, Bosma, Autio, Hunt, De Bono, Servais, Lopez-Garcia, Chin, 2005).

Much of the past comparative research, at the country level, whether for self-employment or aspects of total entrepreneurial activity, has focused primarily on economic factors (Blau, 1987; Blanchflower and Oswald, 1994; Blanchflower, 2000; Evans and Leighton, 1989; Meager, 1992; Acs, Audretsch and Evans, 1994; Audretsch, Thurik, Verheul and Wennekers, 2002; Grilo and Thurik, 2005a and 2005b; Sternberg and Wennekers, 2005). However, a high level of unexplained variation in entrepreneurial activity across countries remains when only economic variables are taken into account (Freytag and Thurik 2007). Thus, more recently, researchers have also looked toward cultural factors to explain this variation (Hofstede, Noorderhaven, Thurik, Uhlaner, Wennekers and Wildeman, 2004; Wennekers, Thurik, Van Stel and Noorderhaven, 2007; Noorderhaven, Thurik, Wennekers and Van Stel, 2004). Most published studies to date use the variables developed by Hofstede to measure the cultural values, individualism, masculinity, uncertainty avoidance and power distance (Hofstede, Noorderhaven, Thurik, Uhlaner, Wennekers and Wildeman, 2004; Wennekers, Thurik, Van Stel and Noorderhaven, 2007; Noorderhaven, Thurik, Wennekers and Van Stel, 2004). The current study provides an opportunity to examine more specifically the effects of postmaterialism on total entrepreneurial activity, which combines rates for nascent entrepreneurship and new business formation. ${ }^{1}$

The understanding of the influence of cultural values is important because these characteristics are imbedded in the population and change more slowly than does economic policy, and may thus provide one explanation for differential effects of similar economic policies on entrepreneurship across cultures. Research evidence by Inglehart (1990) suggests that postmaterialism, though strongly and positively correlated with the economic well-being of a country's citizens, changes more slowly than the economic climate itself, and so may reflect an aspect of cultural values embedded in society. This should help to explain residual effects over and above what can be explained by economic factors themselves.

Section two of the paper provides background about the concepts of culture and postmaterialism. It also reviews some of the antecedents, correlates and consequences of postmaterialism. Section three presents the model and hypotheses tested, including further elaboration of the rationale for the linkage between postmaterialism and entrepreneurial activity. Sections four through seven present the method, results, discussion, and conclusion sections, respectively.

\section{Culture and postmaterialism}

This section reviews the basic terminology used with respect to culture, and more specific background regarding the variable of postmaterialism. This section also reviews some of the antecedents, correlates, and consequences of postmaterialism, including an explanation for why postmaterialism may be related to entrepreneurial behavior.

\subsection{Definition of culture}

The notion of patterns of values which shape human behavior is common to different definitions of culture (Kroeber and Parsons, 1958; Hofstede, 1980). In some of the literature, the view is taken that cultural values are typically determined early in life (Hofstede, 1980; Barnouw, 1979) and tend to endure over time (Hofstede, 1980; Mueller and Thomas, 2000). Other researchers take a somewhat different view, that although certain values may prevail in a particular culture at a moment in time, over time shifts may take place from generation to generation, especially in societies undergoing radical industrial transformation. Thus, for instance, Kotzé and Lombard (2003) examine the shift 
in South Africa's value priorities from prematerialist to materialist between 1990 and 2001 and Inglehart examines the shift among Americans and West Europeans toward postmaterialism between 1970 and 1988 (Inglehart, 1990).

\subsection{Postmaterialism and the cultural dimension}

Though less frequently used in macro-economic research as a predictor of economic activity than the cultural indices developed by Hofstede (1980), Inglehart's (Inglehart, 1977; 1990; 1992; 1997; 2000) work on postmaterialism as a cultural attribute is well established. Inglehart uses the concept of postmaterialism to help explain observed changes in values in modern societies. More generally, the postmaterialism hypothesis describes the transformation in many countries from a culture dominated by materialistic-oriented individuals to a society in which an increasing proportion of the population favors non-materialistic life-goals over materialistic ones. Though beyond the scope of the current study, in recent research, the concept of the postmaterialism index has been expanded to include the notion of prematerialism (prior to a materialist culture) to provide better representation of values in developing countries (Kotzé and Lombard, 2003).

The hypothesis of postmaterialism is based on two subhypotheses, that of socialization and that of scarcity. The socialization hypothesis assumes that one's values reflect to a great extent the prevailing circumstances during his formative years. The scarcity hypothesis assumes that someone's priorities reflect his socio-economic circumstances; therefore he attaches greatest value to relatively scarce goods (DeGraaf, Hagenaars, and Luijkx, 1989; Inglehart, 1981). Taken together, these two hypotheses imply that, as a consequence of the unprecedented prosperity and the absence of war in Western countries since 1945, younger birth cohorts attach less importance to economic and physical security (materialistic values) than older birth cohorts who experienced poverty (and/or other ravages associated with war) in their early years. Instead, younger birth cohorts give higher priorities to non-material goals such as esteem, self-realization and quality of life (postmaterialist values), often referred to in the psychology literature as Maslow's “higher order needs” (Maslow, 1954).

In his research, Inglehart's (1990) findings support the conclusion that the primary reason for the shift toward postmaterialism is due to intergenerational replacement, and not to changes in values to individuals within their own life spans. A consequence of this shift is a declining emphasis on economic growth in these countries, together with an increasing emphasis on the protection of the environment and the quality of life. Other research on postmaterialism shows that, in countries with a prevailing postmaterialist climate, the emphasis on income attainment is smaller than in materialistic countries (De Graaf, 1988), supporting Inglehart's description of postmaterialist cultures as "economic underachievers". The assumption of stability of postmaterialist value-orientations within a culture over relatively long periods of time is supported by extensive empirical research from De Graaf using panel-data for the period 1974-1985 (De Graaf, 1988), as well as others (Dalton 1984; De Graaf, Hagenaars en Luijkx 1989; Niehof, 1992; Van Deth, 1984). More recent research shows that the trend toward postmaterialism may be slowing (De Graaf, 1996) or even declining (Van Deth, 1995). Regardless of direction, the bulk of the research shows that these values are very slow to change within particular cultures. Furthermore, as noted in the introduction, research by Inglehart (1990) supports the view that postmaterialism is only partly influenced by economic climate.

\subsection{Views regarding the relationships between cultural values and entrepreneurial}

\section{behavior}

Since extensive research at the individual level of analysis shows a link between values, beliefs and behavior, it is plausible that differences in national culture, in which these values and beliefs are imbedded, may influence a wide range of behaviors, including the decision to become self-employed rather than to work for others (Mueller and Thomas, 2000). Using this logic, several past studies have explored the relationship between various aspects of culture and entrepreneurial behavior across cultures (Busenitz, Gómez and Spencer, 2000; Davidsson, 1995; Huisman, 1985; Lee and Peterson, 2000; McGrath and MacMillan, 1992; Mueller and Thomas, 2000; Tiessen, 1997; Wennekers, Thurik, Van Stel and Noorderhaven, 2007). The remainder of this section introduces first the notion of push versus pull factors as influences on entrepreneurship, more generally, and then the specific models related to culture, which parallel the views of these opposite forces.

\subsubsection{Push versus pull factors as influences on entrepreneurship}

Applicable to both economic and cultural factors is the notion of supply or push and demand or pull factors for business start-up and entrepreneurship in general (Stanworth and Curran, 1973; Audretsch, Carree, Van Stel and Thurik, 2005; Verheul, Wennekers, Audretsch and Thurik, 2002; Wennekers, Thurik, Van Stel and Noorderhaven, 2007). ${ }^{2}$ Pull factors are concerned with the expectation of being better off as an entrepreneur. Thus, individuals are often at- 
tracted to entrepreneurship, with the expectation that it will provide greater material and/or nonmaterial benefits. As we will explain in more detail in this paper, the predicted impact of materialism/postmaterialism follows this view. Push factors take into account the conflict between one's current and one's desired state. Push factors are often associated with some level of dissatisfaction. Huisman and De Ridder (1984) report that frustrations with previous wageemployment, unemployment and personal crises are among the most cited motives of a large sample of entrepreneurs in eleven different countries. ${ }^{3}$

\subsubsection{Different theories on the relationship between cultural values and entrepreneurial activity}

We can see a parallel to the push-pull argument in three different perspectives regarding the influence of cultural differences. Hypotheses on the relationship between cultural indicators and entrepreneurship differ, depending upon whether one chooses to view the relationship from one of the "pull" perspectives, such as the aggregated psychological traits perspective or social legitimation perspective, or, by a "push" perspective such as the dissatisfaction perspective (Davidsson, 1995; Noorderhaven, Thurik, Wennekers and Van Stel, 2004; Hofstede, Noorderhaven, Thurik, Uhlaner, Wennekers and Wildeman, 2004).

The aggregate psychological traits perspective explains differences in rates of entrepreneurial activity as follows: if there are more people with entrepreneurial values in a country, there will be an increased number of people displaying entrepreneurial behaviors (Davidsson, 1995: 42; also see Shane, 1993: 67). Davidsson notes that this is essentially the perspective also taken by McClelland (1975) and other proponents of the individualistic view of culture.

The "legitimation" or "moral approval" of entrepreneurship focuses on the impact of social norms and institutions on society-at-large (Etzioni, 1987: 182-183). This view claims that greater rates of entrepreneurship are found in societies where the entrepreneur is viewed with higher social status, attention to entrepreneurship is paid within the educational system, and more tax incentives exist to encourage business start-ups. This results in higher demand for and supply of entrepreneurship (Etzioni, 1987: 175). Although the direction of the predictions are the same for the legitimation and aggregated psychological traits perspectives, the explanations differ. Thus, in the legitimation view, the effect is due to institutional and cultural influences, whereas in the aggregated psychological traits view, the effect is due to aggregated effects of individual characteristics. For instance, in the legitimation view, more individuals value entrepreneurship as a result of the higher social status conferred on entrepreneurs in certain societies, whereas in the aggregated psychological traits view, the average person simply indicates that he holds entrepreneurs in high esteem. Although the theoretical explanations may differ, it may be difficult, especially at the macro level, to test empirically which of these explanations is correct since cultural indices are drawn from aggregating responses by individuals.

The dissatisfaction perspective leads to opposite predictions than those derived from the first two views. This explanation for entrepreneurship at the macro level assumes that variation in entrepreneurship is based upon differences in values and beliefs between the population as a whole and potential entrepreneurs. Thus, in a predominantly non-entrepreneurial culture, a clash of values between groups may drive would-be entrepreneurs into selfemployment (Baum et al., 1993: 505; Noorderhaven, Thurik, Wennekers and Van Stel, 2004). There is some empirical support for the dissatisfaction hypothesis in research on culture and self-employment (Wennekers, Thurik, Van Stel and Noorderhaven, 2007; Hofstede, Noorderhaven, Thurik, Uhlaner, Wennekers and Wildeman, 2004). For instance, countries with stronger uncertainty avoidance, that is, the extent to which the members of the culture feel threatened by uncertain or unknown situations (Hofstede, 2001, p. 161), appear to be characterized by higher rates of self-employment (Baum et al., 1993; Etzioni, 1987; Noorderhaven, Thurik, Wennekers and Van Stel, 2004; Hofstede, Noorderhaven, Thurik, Uhlaner, Wennekers and Wildeman 2004). The predicted relationship between the cultural indicators and entrepreneurship according to the dissatisfaction hypothesis is thus the opposite of that which might be expected according to the aggregate psychological trait or the legitimation views (Wennekers, Thurik, Van Stel and Noorderhaven, 2007; Hofstede, Noorderhaven, Thurik, Uhlaner, Wennekers and Wildeman, 2004).

\subsection{Control variables and correlates of postmaterialism}

\subsubsection{Economic climate and postmaterialism}

Postmaterialist values emerge among birth cohorts that grew up under conditions that enable one to take survival for granted (Inglehart, 2003). Thus, the economic climate of the country may have an important effect on postmaterialist values. During the past 25 years, these values have become increasingly widespread throughout ad- 
vanced industrial societies (Inglehart, 2003). In spite of the obvious relationship between these two variables, Inglehart (1990) notes that there is no one-to-one relationship between economic level and the prevalence of postmaterialist values because postmaterialist values reflect one's subjective sense of security, not one's economic level per se. Although the wealth of a nation certainly has an influence, these feelings are also driven by the cultural setting and social welfare institutions of that country, for instance the types of 'safety nets' or other supports provided in case of sickness, loss of work, or other calamity. In short, the scarcity hypothesis alone does not predict value change. Thus, to understand better the separate impact of postmaterialism on rate of total entrepreneurial activity, it is important to control for economic factors. Research by Wennekers, Van Stel, Thurik and Reynolds (2005) identifies per capita income as an economic predictor of nascent entrepreneurship. This variable is therefore chosen as a control in the current study.

Recent research suggests that economic conditions drive change in cultural values, rather than the reverse. In particular, Inglehart (2003) concludes that democratic institutions do not automatically produce a culture that values self-expression. Rather, it seems that economic development must precede social and cultural changes that make democratic institutions more likely to survive and flourish (Inglehart, 2003). In short, there is strong evidence that the causal connection works from economics to politics, not the reverse. Inglehart (2003) also concludes that authority patterns within organizations seem to be shifting from the traditional hierarchical style toward a more collegial style in organizations as well. This shift may also help to explain the decrease in entrepreneurship in postmaterialist societies, since people may more easily be able to find ways to meet needs for self-expression within larger organizations in such cultures, without having to resort to self-employment.

\subsubsection{Life satisfaction and postmaterialism}

Inglehart (2003) reports a statistically significant and positive relationship between life satisfaction and postmaterialism. More recent research also shows a very strong relationship between values towards gender equality and postmaterialism (Inglehart and Norris, 2003). By contrast, societies that rank high on survival values tend to emphasize materialist values, show relatively low levels of subjective well-being and report relatively poor health. Such societies have also been found to be relatively less tolerant toward "outgroups", that is, other groups in the society with dissimilar norms. Such societies are also found to be lower on interpersonal trust, and with greater emphasis on hard work, rather than imagination and tolerance, as important values to teach a child (Inglehart, 2003). ${ }^{4}$

In his research on life satisfaction and economic wealth, Inglehart (1990) concludes that wealthier nations tend to show higher levels of life satisfaction than poorer ones.

Regarding entrepreneurship, the research on life satisfaction and entrepreneurial activity to date has led to contradictory conclusions (Noorderhaven, Thurik, Wennekers and Van Stel, 2004; Verheul, Thurik and Van Stel, 2006). One stream of research suggests that greater life satisfaction may be linked with less entrepreneurial activity, in line with the dissatisfaction hypothesis. Noorderhaven, Thurik, Wennekers and Van Stel (2004) find life dissatisfaction to be positively correlated with self-employment. Verheul, Thurik and Van Stel (2006) find just the opposite, that is, a positive link between life satisfaction and total entrepreneurial activity, especially for women. Either way, reviewing these studies, we consider life satisfaction an important control variable in a model of postmaterialism, in order to tease apart the effects of well-being per se (i.e. life satisfaction) from values associated with postmaterialism, especially since the two variables have been found to be positively correlated in previous studies.

\subsubsection{Education and postmaterialism}

The importance of education in prediction of occupation has long been recognized in sociological research. For instance, in an extensive study on the American occupational structure, Blau and Duncan (1967) conclude that educational attainment is a more important predictor of someone's occupation than background characteristics, such as the father's occupation or education. They also conclude that the intergenerational mobility within business families increases and, as a result, children of business owners choose to pursue a different career than their parents. More recent research at the individual unit of observation suggests that both nascent entrepreneurship (Delmar and Davidsson, 2000; Davidsson and Honig, 2003) and self-employment ${ }^{5}$ (Robinson and Sexton, 1994; Cooper and Dunkelberg, 1987) are influenced positively by educational attainment. ${ }^{6}$ However, macro research tends to show the opposite effects. Thus, a study at the macro level by Uhlaner, Thurik and Hutjes (2002) shows that a higher level of education in a country is accompanied by a lower self-employment rate. Since higher educational attainment is highly

\footnotetext{
4 For more detailed discussion of the outgroup concept and its implications, see, for instance, Mackie, et al (1992) and Baron and Kerr (2003).

5 Self-employed people here refer to people who have moved beyond the nascent entrepreneurship stage.

6 See also Grilo and Thurik (2005a and 2005b) and Parker (2004).
} 
correlated with economic indicators, such as per capita income. In wealthier countries, individuals with more education have greater opportunity to achieve equal or higher social status when employed by others. Thus, entrepreneurship is no longer the only path leading away from lower socio-economic positions. Other research also supports the notion that education may be indirectly linked to a lower rate of entrepreneurship due to its inverse relationship to unemployment (Audretsch, Thurik, Verheul and Wennekers, 2002), which may be viewed as a push factor towards business ownership.

Coupled with this research are other findings that show a fairly strong positive relationship between levels of education and postmaterialism (Inglehart, 1997). Rising levels of education lead to rising levels of postmaterialist values. These findings, together with those (negatively) linking education and business ownership, lead us to suggest that postmaterialist values may mediate the relationship between education and total entrepreneurial activity. Given this past research, education was chosen as a control variable, but with a distinction between secondary and tertiary education rates.

\section{Model and hypotheses}

The underlying premise of this study is that nonmaterial motives for entrepreneurs notwithstanding: a) material gains are central or crucial to entrepreneurship; and b) since those gains, by definition, are of less value to postmaterialist individuals, a society that is more postmaterialist is likely to be less entrepreneurial, other things being equal. This premise is closely linked to the psychological aggregate perspective in that it assumes that, in the aggregate, a society with fewer materialistic individuals will also have fewer entrepreneurs. Some researchers assert that nonmaterial motives such as need for autonomy (Van Gelderen and Jansen, 2006) or dissatisfaction with the previous work itself (Brockhaus, 1982) may be associated with entrepreneurial intentions or behaviors. However, the primary focus here is on the link between evidence that entrepreneurs are motivated, at least in part, by material gain. This premise has not been tested previously at the macro-level of analysis, but research aggregating individual responses provides some support for this argument. For instance, McGrath, MacMillan and Scheinberg (1992) find that individual business owners from a wide variety of countries are more likely to have materialistic values. Entrepreneurs in their study are more likely to define success as 'making lots of money' than their non-entrepreneur counterparts. However, they do not test for country differences. Blais and Toulouse (1990) do make such comparisons and conclude that entrepreneurs across countries tend to have similar motivations - in particular, that entrepreneurs place greater value on material gain than nonentrepreneur counterparts. In another study of individual entrepreneurs, Robichaud, McGraw and Roger (2001) find a positive correlation between extrinsic motivation of the entrepreneur and sales performance. They find negative relationships between intrinsic motivation, autonomy and independence and the dependent variable, sales performance.

To sum up, research to date, although primarily at the micro-level of analysis (i.e. comparison of individual entrepreneurs), supports the thesis that business owners, especially successful ones, are more materialistic than their counterparts being employed or unemployed. We make the link that, if indeed a society as a whole is more materialistic (as measured by the postmaterialism scale), the values of the society are more closely aligned with the goals of individual entrepreneurs. Lacking comparable research at the macro-level of analysis, using the aggregated psychological traits view (and/or the legitimation view), we predict that, in societies where making money is less highly valued by the average person, the rate of entrepreneurship is also likely to be lower. We state this as follows:

Hypothesis 1: The more postmaterialist the culture, the lower the rate of total entrepreneurial activity.

From past research evidence that shows a correlation between postmaterialism and other societal level characteristics, including per capita income, education, and life satisfaction, one might argue that the influence of postmaterialism could be spurious, or at least intertwined with these other factors. Thus, a second hypothesis posits a "culture" effect of postmaterialism values, even when controlling for these other variables. To summarize, we state Hypothesis 2 as follows:

Hypothesis 2: Controlling for per capita income, education, and life satisfaction, there remains an independent (negative) influence of postmaterialism on rate of entrepreneurial activity.

\section{Research method}

\subsection{Data and variables}

In order to test our central hypothesis about the influence of postmaterialism on entrepreneurial activity, data are used from different sources, including the Global Entrepreneurship Monitor (GEM) (Reynolds, Bygrave, Autio, Cox, and Hay, 2002), World Value Surveys (Inter-University Consortium for Political and Social Research (ICPSR), 1994), and the World Development Indicators database of the World Bank (2001, 2002). Details on the different variables used in the research are presented in Appendix 1. The primary measure for postmaterialism is based upon Inglehart's four-item postmaterialism index and data collected in 1990 as part of the World Values Survey 
1990-1993 (ICPSR, 1994). The four item index was selected because there appears to be more complete data across countries for this shorter index. Furthermore, the 1990 dataset is used because it is more complete dataset than the dataset for either the 1981 or 1995-97 data collection periods.

Because of the known interactions between economic, social, demographic and cultural factors found in previous research, a set of control variables is also included to test for independent and/or mediating effects that postmaterialism may have in predicting the rate of entrepreneurial activity. Control variables include per capita income and per capita income squared, percentage of the population in the appropriate age range in secondary education, percentage of the population in the appropriate age range in tertiary education, and life satisfaction. Total entrepreneurial activity is made up of two components: nascent entrepreneurship and new business formation. For comparison purposes, in certain analyses, other dependent variables were substituted for total entrepreneurial activity, including rate of established business and total business ownership (which combines new business formation and established business together, but excludes nascent entrepreneurship) (See Appendix 1).

\subsection{The sample}

Across the different datasets used for the study, twenty-seven countries had complete data, including Argentina, Belgium, Brazil, Canada, Chile, China, Denmark, Finland, France, Germany (Western), Hungary, India, Ireland, Italy, Japan, Korea, Mexico, Norway, Poland, South Africa, Slovenia, Spain, Sweden, Switzerland, the Netherlands, the United Kingdom and the United States.

\subsection{Data analysis}

To test for Hypothesis 1, postmaterialism is regressed alone against the dependent variable of total entrepreneurial activity. Bivariate correlations are also computed to examine the effects of individual variables on the dependent variable of total entrepreneurial activity.

To test Hypothesis 2 multiple regression analysis is used in a series of models carried out to determine the effects of different variables, and possible mediating effects, using an approach described in Verheul, Uhlaner and Thurik (2005). Briefly, in each case, the control variable is entered first. The significance of the change in R-squared is computed when postmaterialism is added to the model. For the per capita income variable, since past research suggests a curvilinear effect on total entrepreneurial activity, preliminary analyses includes both the linear and squared term for per capita income. However, since the squared term adds nothing to the overall models, it is excluded from more detailed analyses. 7

In addition to test the main hypotheses, with total entrepreneurial activity as dependent variable, similar regression analyses are carried out, using differing dependent variables, including nascent entrepreneurship, new business formation, established business and total business ownership rates. For all regressions, a VIF statistic and tolerance are computed to test for multicollinearity effects. A tolerance greater than .10 is used as a determinant of significance of multicollinearity effects. The VIF statistics are not reported here, but all tolerances were above .10, with the exception of per capita income and per capita income squared, when included together in the same model, as might be expected.

\subsection{Tests for robustness}

To test for robustness of the primary model (all variable model in Table 2), two tests are carried out. First, the all-variable multiple regression models are calculated for prediction of total entrepreneurial activity for each of 27 subsamples, omitting one of the countries each time as a test for outlier effects.

In a second test of robustness, other postmaterialism indices (including the four-item measures for 1981 and 1995-1997) are substituted in prediction of new business formation and total entrepreneurial activity.

\section{Results}

\subsection{Initial test of Hypothesis 1: Bivariate tests and other bivariate relationships}

In an initial test of hypothesis 1, using the Pearson Product-Moment Correlation coefficient, postmaterialism negatively relates to total entrepreneurial activity, consistent with the prediction made in Hypothesis $1(\mathrm{r}=-.37, \mathrm{p}<.05$, 
$\mathrm{n}=29$ ) (see Table 1). Examining the subcomponents of total entrepreneurial activity separately, postmaterialism is more strongly (and negatively) linked to new business formation $(\mathrm{r}=-.45, \mathrm{p}<.05)$ than to nascent entrepreneurship $(\mathrm{r}=-.23, \mathrm{~ns})$. Results of other bivariate tests for independent, control, and dependent variables are also presented in Table 1. Postmaterialism is positively associated with per capita income $(r=.70, p<.01)$, life satisfaction $(r=.68$, $\mathrm{p}<.01)$, secondary education $(\mathrm{r}=.59, \mathrm{p}<.01)$ and tertiary education $(\mathrm{r}=.62, \mathrm{p}<.01){ }^{8}$

Table 1 about here

\subsection{Test of Hypotheses 2 using Total Entrepreneurial Activity as dependent variable}

Table 2 presents a summary of the multiple regression analyses carried out on total entrepreneurial activity. When controlling separately first for per capita income and per capita income squared, postmaterialism does not contribute to the explanation of the model (Model 2). The same is true for education (Model 3). However, when postmaterialism is added to a model with life satisfaction, the additional explanation $\left(\Delta \mathrm{R}^{2}\right)$ is significant, suggesting that postmaterialism adds independent effects to the overall model with life satisfaction (Model 4). Furthermore, when all three control variables are combined with postmaterialism (Model 5), postmaterialism once again makes an added independent contribution to the model $\left(\Delta \mathrm{R}^{2}=.07, \mathrm{p}<.05\right)$. Adding the per capita income-squared term does not substantially change the remaining effects, except, as would be expected, the linear per capita income term.

Table 2 about here

Table 3 presents a series of additional regressions, with the same independent and control variables, but with different dependent variables. It would appear from these results, for instance, that, although the total R-squared is roughly the same, the contribution of postmaterialism to explanation of overall variance is much stronger for new business formation $(B=-9.77, t=-4.45, p<.-001)$ than for the nascent entrepreneurship rate, which is not significant $(B=-1.13$, $\mathrm{t}=-.45$, ns). Postmaterialism does not predict the rate of established businesses. The final model, dealing with the prediction of total business ownership, once again shows the predictive power of postmaterialism, but this is probably due to the fact that one component of total business ownership, new business formation (which was previously shown to be predicted by postmaterialism), plays an important role.

Table 3 about here

In sum, comparing the models presented in Table 3 , and consistent with bivariate statistics presented in Table 1, the data suggest that postmaterialism most clearly predicts new business formation, in contrast to either nascent entrepreneurship or established businesses. ${ }^{9}$ The effects of the different control variables also differ depending upon the choice of dependent variable. Thus, the effect of per capita income all but disappears in the models predicting the rate of nascent entrepreneurship, new business formation, and established business. Secondary education has a negative effect on both components of total entrepreneurial activity, but not on the rate of established firms. Similarly, both life satisfaction and tertiary education have positive effects on both subcomponents of total entrepreneurial activity. However, neither is a significant predictor for the rate of established businesses.

\subsection{Results of tests for robustness}

As pointed out by Beugelsdijk, de Groot, and van Schaik (2004), there is no uniform test for robustness. Given the small sample size, some tests for robustness are not considered practical. However, to check for robustness with respect to the composition of the sample, regressions for the primary model shown in Table 2 (model 5) are re-

\footnotetext{
8 An earlier version of the paper (Uhlaner and Thurik, 2004) reports relationships between these variables and different cultural indices measured by Hofstede, including power distance, individualism, masculinity, and uncertainty avoidance. The Hofstede indices are also substituted for postmaterialism in a series of multiple regression analyses (Uhlaner and Thurik, 2005).

9 In other analyses, not shown here, postmaterialism is a significant negative predictor of nascent entrepreneurship, but only in a regression model with life satisfaction as a positive predictor.
} 
peated for 27 subsamples, omitting one of the countries each time. The resulting adjusted R squared ranges from .74 to .82. Though minor fluctuations occur, the model remains fairly stable. With Korea omitted, the model is somewhat weaker (only a trend of $\mathrm{p}<.10$ rather than significance level of $\mathrm{p}<.05$ for the change in $\mathrm{R}$ squared of postmaterialism when added to the other variables in prediction of total entrepreneurial activity) but the fluctuations are minor.

In a second test of robustness of the effect of postmaterialism, postmaterialism indices from different years (including 1981 and 1995-1997) are substituted for the index from 1990 to predict total entrepreneurial activity and new business formation (See Table 4). Similar patterns of results are found, although due to much smaller sample sizes, the results do not always hold at the same level of statistical significance. In comparing the models, the 1995-7 models are fairly similar. However, the significance level is lower, perhaps due to the fact that fewer countries (20 vs. 27) are included in the sample. The B value for the 1981 postmaterialism index is also negative but not significant at the .05 level, again, with a smaller $(\mathrm{n}=18)$ sample.

Table 4 about here

\section{Discussion}

\subsection{Discussion of results}

The results of this study confirm the importance of postmaterialism when explaining total entrepreneurial activity, but especially new business formation. In reviewing the two hypotheses as initially stated in this paper, there does appear to be reasonable support for Hypothesis 1, predicting a negative relationship between postmaterialism and total entrepreneurial activity. Support for Hypothesis 2 depends upon whether all controls are viewed together in the model (in which case, the Hypothesis 2 is supported), or separately (in which case, in some instances it is not). Lack of stability of findings does suggest some rather complex interrelationships amongst the control and independent variables. However, one possibility is that postmaterialism mediates the relationship between per capita income and total entrepreneurial activity, consistent with Ingelhart's conclusions that economic climate drives social change, rather than the reverse (Inglehart, 1990). However, the results supporting such a conclusion are ambiguous. Indeed, in Model 5, the fact that the B weight for per capita income becomes non-significant when all variables (including postmaterialism) are added to the model would support the claim that postmaterialism mediates the relationship between economic climate and entrepreneurial activity. ${ }^{10}$ However, results from Model 2 would lead one to the opposite conclusion (that economic activity mediates the relationship between postmaterialism and entrepreneurial activity). Clearly, further research is needed to tease apart these effects, perhaps on regional data which would provide a larger sample size.

Regarding effects of the different control variables, per capita income also has a negative effect, whether included alone or with the rest of the variables in the model. Preliminary regression analyses check for the possibility of a curvilinear effect of per capita income on total entrepreneurial activity (Carree, Van Stel, Thurik and Wennekers, 2002; Wennekers, Van Stel, Thurik and Reynolds, 2005; Sternberg and Wennekers, 2005). However, it does not provide additional explanation of the dependent variable when postmaterialism, life satisfaction, per capita income, secondary education and tertiary education are included in the model. Secondary education appears to have a fairly consistent negative effect. Although zero-order effects for tertiary education on total entrepreneurial activity are not significant, the effect of tertiary education on total entrepreneurial activity becomes positive when controlling for all the other variables used in the study (see Models 5 and 6). Finally, life satisfaction, though not significant in zero-order statistics, consistently has a positive effect on total entrepreneurial activity in Models 4, 5, and 6, all of which include postmaterialism.

Results for the control variables are interesting, in comparison with past research. For instance, the negative relationship between per capita income and entrepreneurial activity is in line with findings by Wennekers, Thurik, van Stel and Noorderhaven, (2007) who find higher self-employment in countries with less prosperity (lower per capita GDP). On the other hand, the findings in the current paper contradict findings by Wennekers, Thurik, Van Stel and Noorderhaven (2007) regarding life satisfaction and self-employment (their study finding a negative relationship between the two variables). There are three possible explanations for the differences in these results: a) different sources of data were used in our study versus that of Wennekers, Thurik, Van Stel and Noorderhaven (2007), for 
both life satisfaction and entrepreneurship; b) different samples of countries were used in the two studies, in particular their study limited only to OECD countries whereas our sample includes poor countries; and finally, c) our study is primarily a cross sectional rather than panel study.

Regarding findings for education, consistent with Inglehart's other research, postmaterialism and education are positively related (Inglehart, 1997). However, controlling for other factors, including postmaterialism and life satisfaction, secondary and tertiary education appear to have opposite effects on total entrepreneurial activity - secondary education with a negative and tertiary education with a positive effect. There are different possible explanations for these results. On the one hand, perhaps more widespread secondary education reduces the need for selfemployment, and is a way to detect not only average income but also wider dispersion of income and employment opportunity within the population, consistent with other research which shows a negative relationship between secondary education and unemployment (Audretsch, Thurik, Verheul and Wennekers, 2002). On the other hand, the positive effect of tertiary education on total entrepreneurial activity suggests that higher level education may provide a larger pool of would-be entrepreneurs attracted to the nonmaterial rewards of entrepreneurship, such as greater autonomy (Van Gelderen and Jansen, 2006) or achievement (McClelland, 1975). Perhaps tertiary education also provides human capital for 'high-tech' entrepreneurship initiatives. Certainly more research is warranted that would examine different levels of education as separate dummy variables rather than assuming a linear relationship between education and entrepreneurial activity.

\subsection{Limitations and directions for future research}

This study is limited by its small sample size (twenty-seven countries) and by its particular period of time (2002). For clarity regarding time lags, all variables reflect a measurement in one point in time. Sometimes the year chosen was more for practical reasons (more countries available for instance for 1990 than for 1981 and 1995-97 for the postmaterialism index). However, it is possible that the relationships may alter if data are examined from different periods of time and/or different sets of countries. The relatively small number of cases also leaves open some unresolved questions of robustness. As reported earlier, findings are reasonably robust, though omitting one or two countries (Korea in particular) modifies the statistical significance of the postmaterialism index somewhat for total entrepreneurial activity (from the .05 level to the .10 level of significance for the delta R-squared), although the signs remain the same. The effect of Korea, in particular, on the model suggests the need to sample from a more diverse group of countries, and, in particular, to represent Asian countries more broadly. Korea and Japan are the only two Asian countries with data available from both GEM and the World Values Survey. In short, conclusions drawn from this study should be viewed as tentative, at best. However, the strength and size of the findings, with respect to their significance levels and amount of variation explained, suggest possible benefits of pursuing the impact of postmaterialism on rate of total entrepreneurial activity, and new business formation, in particular.

Future research should explore the construct validity of the different cultural indices used in past and present research in entrepreneurial economics. Furthermore, longitudinal effects would be helpful in order to examine the stability and direction of change of postmaterialism in different cultures, although this is hampered somewhat by erratic data collection not only for postmaterialism but also possibly for other social and cultural variables. The present work suggests that it may be worth the effort to continue exploring these effects and the way in which they interact with one another and with economic and demographic variables at the country level, especially given the radical redefinition of many country borders within the past few decades, more refined analyses of subregions within countries and/or "supraregions" across countries (see Hofstede, Noorderhaven, Thurik, Uhlaner, Wennekers and Wildeman, 2004) may also yield interesting results.

In future research, it may be useful to consider carefully the differences in factors predicting nascent entrepreneurship, new business formation and the overall established business rate. For instance, for nascent and young entrepreneurs, factors that predict motivation and intentions may be more important than those that determine actual skill levels. Thus, push factors, such as secondary education, may trigger feelings of job security and act as a brake on entrepreneurial activity in the start-up phase, but have a much weaker effect, if any, on the determination of the rate for established firms. Tertiary education, in contrast, might be a reflection of the total human capital of a country, i.e. the specialized skills and abilities needed to launch high-technology or other knowledge-based firms.

Regarding postmaterialism and entrepreneurial activity, findings from the present study might be interpreted using the aggregated psychological traits view. That is, less postmaterialist cultures may have a larger proportion of individuals motivated by money, and in turn, successful at making (their first) sales. This does not explain why postmaterialism does not lack predictive power for other business ownership rates, including nascent entrepreneurship and established business ownership.

The lack of power of any of the selected factors to predict the rate of established firms is indeed puzzling, although the signs are in the same direction. Perhaps motivational factors become far less important in prediction of the survival of firms than various environmental factors, including institutional differences and economic policies which differ across countries. The economic literature is replete with examples of such explanations. A number of 
studies explain, for instance, the rebound in self-employment in the late twentieth century on supply factors such as tax rates, unemployment, competition and female labor participation (Blau, 1987; Blanchflower and Oswald, 1994; Blanchflower, 2000; Evans and Leighton 1989; Meager 1992, Acs, Audretsch and Evans, 1994; Audretsch, Thurik, Verheul and Wennekers, 2002). Differences in taxation policies, population density, investment in infrastructure (for roads, schools, etc.) are other factors that have been shown to help explain regional differences in incorporation rates across U.S. states (Hendrickson and Woodland, 1985). In summary, more accurate explanations of variation in business ownership may require differentiated models to predict nascent entrepreneurship, new business formation, and business survival rates, taking into account a variety of variables based on human capital (extrapolated from demographic variables such as education), culture (not just postmaterialism but other values), and economic policies (determining not only the average but also dispersion of resources within a society).

\section{Conclusion and Practical Implications of the Research}

The focus of this paper is on the determinants of entrepreneurial activity. Much of past research in this area has been dominated by investigation of economic factors. This study is not intended to discount the role that governmental policies play in stimulating self-employment and entrepreneurship. However, the results of this study provide support for the conclusion that cultural values, in this case, postmaterialism, may provide an added explanation for differing rates of entrepreneurial activity across countries. One implication of these results is that the effectiveness of various policy responses may be limited partially by cultural factors beyond the control of policy makers. Alternatively, policies to stimulate entrepreneurship in the future might be customized toward the cultural biases present in a particular society. Thus, for instance, in a more postmaterialist culture, it may be important to emphasize the nonmaterial benefits of launching one's own firm (autonomy, creativity, etc.) rather than on the economic benefits.

Two caveats are appropriate here. First, even if the relationship between postmaterialism and rate of total entrepreneurial activity holds across nations, it may not hold true for individuals within countries. The extent of materialist values at the individual level may play a role in predicting entrepreneurship behavior within countries, but this cannot be concluded from this cross-national study. Second, one must be prudent in extrapolating the conclusions found in this study to worldwide relationships. This study is based on a range of countries on four continents (North and South America, Europe, and Asia). However, it is limited to only twenty-seven countries. This limitation, nonetheless, does not disqualify important findings from this study, which show that, for the countries under study, at least one aspect of national culture - postmaterialist values - may have powerful effects on the rate of entrepreneurial activity, especially the rate of new business formation.

In summary, our findings clearly confirm a negative relationship between postmaterialism and entrepreneurial activity; countries marked by less materialistic values tend to have lower total (nascent and new business formation combined) entrepreneurial activity as a proportion of the adult population. Further, per capita income and the proportion of the population enrolled in secondary level education are both negatively associated with total entrepreneurial activity, whereas life satisfaction and tertiary education levels have the opposite effect, when other variables are controlled for. Other than the linear and squared term of per capita income, in spite of relatively high intercorrelation among the variables of the present study, multicollinearity is not a problem, and it appears that each variable contributes a unique and fairly consistent portion of the variance explained for the dependent variable of total entrepreneurial activity. However, further research is still warranted to confirm the stability of this relationship in a broader sample of countries and where available, with longitudinal data.

\section{References}

Abramson P, Inglehart R (1999) Measuring postmaterialism. American Political Science Review 93 (3): 665 677

Acs ZJ, Audretsch DB, Evans DS (1994) The determinants of variations in self-employment rates across countries over time. Discussion paper 871. Centre for Economic Policy Research, London

Audretsch DB, Carree MA, Van Stel AJ, Thurik AR (2005) Does self-employment reduce unemployment. Discussion paper D5057. Centre for Economic Policy Research, London

Audretsch DB, Thurik AR, Verheul I, Wennekers ARM (2002) Entrepreneurship: determinants and policy in a European-US comparison. Kluwer Academic Publishers, Boston/Dordrecht

Barnouw V (1979) Culture and personality. The Dorsey Press, Homewood, IL

Baron RS, Kerr NL (2003) Group process, group decision, group action. Second edition. Open University Press, Maidenhead, Berkshire, UK

Baum JR, Olian JD, Erez M, Schnell ER, Smith KG, Sims HP, Scully JS, Smith KA (1993) Nationality and work role interactions: a cultural contrast of Israeli and US entrepreneurs' versus managers' needs. Journal of Business Venturing 8 (6): 499-512

Beugelsdijk S, De Groot HLF, Van Schaik ABTM (2004) Trust and economic growth: a robustness analysis. Oxford Economic Papers 118: 118-134 
Blais RA, Toulouse J (1990) National, regional or world patterns of entrepreneurial motivation? An empirical study of 2,278 entrepreneurs and 1,733 non-entrepreneurs in fourteen countries on four continents. Journal of Small Business and Entrepreneurship 7 (2): 3-20

Blanchflower DG (2000) Self-employment in OECD countries. Labour Economics 7 (5): $471-505$

Blanchflower DG, Oswald AJ (1994) The wage curve. MIT Press, Cambridge, MA

Blau D (1987) A time series analysis of self-employment. Journal of Political Economy 95 (3): $445-467$

Blau PM, Duncan OD (1967) The American occupational structure. John Wiley, New York, NY

Brockhaus RH (1982) The psychology of the entrepreneur. In: Kent CA, Sexton DL, Vesper KH (eds) Encyclopedia of entrepreneurship. Prentice-Hall, Inc, Englewood Cliffs, NJ

Busenitz LW, Gómez C, Spencer JW (2000) Country institutional profiles: unlocking entrepreneurial phenomena. Academy of Management Journal 43 (5): 994-1003

Carree M, Van Stel AJ, Thurik AR, Wennekers ARM (2002) Economic development and business ownership: an analysis using data of 23 OECD countries in the period 1976-1996. Small Business Economics 19 (3): $271-290$

Cooper AC, Dunkelberg WC (1987) Entrepreneurial research: old questions, new answers and methodological issues. American Journal of Small Business 11 (3): 11-23

Dalton RJ (1984) The persistence of values and life cycle changes. Politische Vierteljahresschrift 12: 189-207

Davidsson P (1995) Culture, structure and regional levels of entrepreneurship. Entrepreneurship and Regional Development 7: 41-62

Davidsson P, Honig B (2003) The role of social and human capital among nascent entrepreneurs. Journal of Business Venturing 18 (3): 301-331

De Graaf ND (1988) Postmaterialism and the Stratification Process: An International Comparison. ISOR, Utrecht

De Graaf ND (1996) Politieke scheidslijnen: ontwikkelingen in de politieke participatie en politieke voorkeuren. In: Ganzeboom HBG, Ultee WC (eds) De sociale segmentatie van Nederland in 2015. WRR rapport V 96. SDU, Den Haag

De Graaf ND, Hagenaars J, Luijkx R (1989) Intragenerational stability of postmaterialism in Germany, the Netherlands and the United States. European Sociological Review 5 (2): 183-201

Delmar F, Davidsson P (2000) Where do they come from? Prevalence and characteristics of nascent entrepreneurs. Entrepreneurship and Regional Development 12 (1): 1-23

Etzioni A (1987) Entrepreneurship, adaptation and legitimation. Journal of Economic Behavior and Organization 8 (2): $175-189$

Evans DS, Leighton LS (1989) The determinants of changes in U.S. self-employment, 1968-1987. Small Business Economics 1 (2): 319-330

Freytag A, Thurik AR (2007) Entrepreneurship and its determinants in a cross country setting. Journal of Evolutionary Economics this issue

Grilo I, Thurik AR (2005a) Latent and actual entrepreneurship in Europe and the US: some recent developments. International Entrepreneurship and Management Journal 1 (4): 441-459

Grilo I, Thurik AR (2005b) Entrepreneurial engagement levels in the European Union. International Journal of Entrepreneurship Education 3 (2): 143-168

Hendrickson L, Woodland L (1985) Application of the population ecology model to the estimation of corporate births. Proceedings United States Association for Small Business and Entrepreneurship. October 13-16. Orlando, Florida

Hofstede G (1980) Culture's consequences: international differences in work-related values. Cross cultural Research and Methodology Series 5. Sage Publications, Newbury Park, CA

Hofstede G (2001) Culture's consequences: comparing values, behaviors, institutions, and organizations across nations. Second edition. Sage Publications, Thousand Oaks, CA

Hofstede G, Noorderhaven NG, Thurik AR, Uhlaner LM, Wennekers ARM, Wildeman RE (2004) Culture's role in entrepreneurship: self-employment out of dissatisfaction. In: Ulijn J, Brown T (eds) Innovation, entrepreneurship and culture: the interaction between technology, progress and economic growth. Edward Elgar, Cheltenham, UK and Brookfield, US: 162-203

Huisman D (1985) Entrepreneurship: economic and cultural influences on the entrepreneurial climate. European Research 13 (4): 10-17

Huisman D, De Ridder WJ (1984) Vernieuwend ondernemen. SMO, Utrecht

Inter-University Consortium for Political and Social Research (1994) World values survey 1981-1984 and 19901993 (codebook). ICPSR, Ann Arbor, MI

Inglehart R (1977) The silent revolution: changing values and political styles among western publics. Princeton University Press, Princeton, NJ

Inglehart R (1990) Culture shift in advanced industrial society. Princeton University Press, Princeton, NJ

Inglehart R (1992) Changing values in industrial societies: the case of North America 1981-1990. Politics and the Individual 2 (2): 1-31 
Inglehart R (1997) Modernization and post-modernization: cultural, economic and political change in 43 societies. Princeton University Press, Princeton, NJ

Inglehart R (2000) Globalization and postmodern values. The Washington Quarterly 23 (1): 215-228

Inglehart R (ed) (2003) Human values and social change: findings from the values surveys. Brill Publishers, Leiden, The Netherlands

Inglehart R, Norris P (2003) Rising tide: gender equality and cultural change around the world. Cambridge University Press, Cambridge, England

Kotzé H, Lombard K (2003) Revising the value shift hypothesis: a descriptive analysis of South Africa's value priorities between 1990 and 2001. In: Inglehart R (ed) Human values and social change: findings from the values surveys. Brill Publishers, Leiden, The Netherlands

Kroeber AL, Parsons T (1958) The concepts of culture and of social system. American Sociological Review 23 (5): 582-583

Lee SM, Peterson SJ (2000) Culture, entrepreneurial orientation, and global competitiveness. Journal of World Business 35 (4): 401-416

Mackie DM, Gastardo-Conaco MC, Skelly JJ (1992) Knowledge of the advocated position and the processing of intergroup and out-group persuasive messages. Personality and Social Psychology Bulletin 18: 145-151

Maslow A (1954) Motivation and personality. Harper and Row, New York

McGrath RG, MacMillan IC (1992) More like each other than anyone else? Cross-cultural study of entrepreneurial perceptions. Journal of Business Venturing 7 (5): 419-429

McGrath RG, MacMillan IC, Scheinberg S (1992) Elitists, risk-takers, and rugged individualists? An exploratory analysis of cultural differences between entrepreneurs and non-entrepreneurs. Journal of Business Venturing 7 (2): 115-136

McClelland DC (1975) Power: the inner experience. Irvington, New York

Meager N (1992) Does unemployment lead to self-employment? Small Business Economics 4 (2): 87-103

Mueller SL, Thomas AS (2000) Culture and entrepreneurial potential: a nine country study of locus of control and innovativeness. Journal of Business Venturing 16 (1): 51-75

Niehof TJ (1992) Postmaterialisme en levensloopeffecten: een onderzoek naar de invloed van een verandering in leefsituatie op postmaterialistische waardenorientaties. Doctoraal thesis. Katholieke Universiteit Nijmegen

Noorderhaven NG, Thurik AR, Wennekers ARM, Van Stel AJ (2004) The role of dissatisfaction and per capita income in explaining self-employment across 15 European countries. Entrepreneurship: Theory and Practice 28 (5): 447-466

Parker SC (2004) The economics of self-employment and entrepreneurship. Cambridge University Press, Cambridge

Reynolds P, Bosma M, Autio E, Hunt S, De Bono N, Servais I, Lopez-Garcia P, Chin N (2005) Global entrepreneurship monitor: data collection design and implementation 1998-2003. Small Business Economics 24 (3): 205-231

Reynolds PD, Camp SM, Bygrave WD, Autio E, Hay M (2001) Global Entrepreneurship Monitor: 2001 Executive Report. Kauffman Center for Entrepreneurial Leadership

Reynolds PD, Bygrave WD, Autio E, Cox LW, Hay M (2002) Global Entrepreneurship Monitor, 2002 Executive Report, Wellesley, MA: Babson College

Robichaud Y, McGraw E, Roger A (2001) Toward the development of a measuring instrument for entrepreneurial motivation. Journal of Developmental Entrepreneurship 6 (2): 189-201

Robinson PB, Sexton EA (1994) The effect of education and experience on self-employment success. Journal of Business Venturing 9 (2): 141-156

Shane S (1993) Cultural influences on national rates of innovation. Journal of Business Venturing 8 (1): 59-73

Stanworth MJK, Curran J (1973) Management motivation in the smaller business. Gower Press, London

Sternberg R, Wennekers S (2005) Determinants and effects of new business creation using global entrepreneurship monitor data. Small Business Economics 24 (3): 193-203

Tiessen JH (1997) Individualism, collectivism, and entrepreneurship: a framework for international comparative research. Journal of Business Venturing 12 (5): 367-384

Uhlaner LM, Thurik AR (2004) Post materialism influencing total entrepreneurial activity across nations. Papers on entrepreneurship, growth and public policy. \#07-2004. Max Planck Institute of Economics, Jena, Germany

Uhlaner LM, Thurik AR (2005) Post materialism influencing total entrepreneurial activity across nations. Workshop on culture and entrepreneurship. February 2005. Max Planck Institute of Economics, Jena, Germany

Uhlaner LM, Thurik AR, Hutjes J (2002) Postmaterialism: a cultural factor influencing entrepreneurial activity across nations. ERIM report ERS-2002-62-STR. Erasmus Research Institute for Management, Rotterdam

Van Deth JW (1984) Politieke waarden: een onderzoek naar politieke waarde-orientaties in Nederland in de periode 1970 tot en met 1982. Dissertation, Amsterdam

Van Deth JW (1995) De stabiliteit van oude en nieuwe politieke oriëntaties. In: Van Holsteyn JJM, Niemoller B (eds) De nederlandse kiezer. DWSO Press, Leiden 
Van Gelderen M, Jansen P (2006) Autonomy as a start-up motive. Journal of Business and Enterprise Development 13 (10): 23-32

Van Uxem FW, Bais J (1996) Het starten van een bedrijf: ervaringen van 2000 starters. EIM, Zoetermeer

Verheul I, Van Stel AJ, Thurik AR (2006) Explaining female and male entrepreneurship across 29 countries. Entrepreneurship and Regional Development 18 (March): 151-183

Verheul I, Uhlaner LM, Thurik AR (2005) Business acomplishments, gender and entrepreneurial self-image. Journal of Business Venturing 20 (4): 483-518

Verheul I, Wennekers S, Audretsch DB, Thurik AR (2002) An eclectic theory of entrepreneurship: policies, institutions and culture. In: Audretsch DB, Thurik AR, Verheul I, Wennekers ARM (eds) Entrepreneurship: determinants and policy in a European-US comparison. Kluwer Academic Publishers, Boston/Dordrecht

Wennekers S, Van Stel AJ, Thurik AR, Reynolds P (2005) Nascent entrepreneurship and the level of economic development. Small Business Economics 24 (3): 293-309

Wennekers S, Thurik AR, Van Stel AJ, Noorderhaven N (2007) Uncertainty avoidance and the rate of business ownership across 21 OECD countries, 1976-2004. Journal of Evolutionary Economics, this issue

World Bank (2001) World development indicators 2001. World Bank 1 (1): 1-396. International Bank for Reconstruction and Development/World Bank, Washington, D.C

World Bank (2002) World development indicators 2002. World Bank 1 (2): 1-432. International Bank for Reconstruction and Development/World Bank, Washington, D.C 


\title{
Appendix: Details regarding measurement of variables
}

\author{
Dependent Variables
}

Data on the entrepreneurial activity variables below are taken from the Global Entrepreneurship Monitor (GEM) 2002 Adult Population Survey (Reynolds, Bosma, Autio, Hunt, De Bono, Servais, Lopez-Garcia, Chin, 2005). This database contains various entrepreneurial measures that are constructed on the basis of surveys of -on average- some 3,000 respondents per country (37 countries in total).

\section{Total Entrepreneurial Activity 2002}

Total entrepreneurial activity is measured as a combination of nascent entrepreneurship (the percentage of people in the age group of 18 to 64 years who are actively engaged in the start-up process) or new business formation (those owning and managing a business less than 42 months old in 2002) (expressed in \% of adults in the same age group). Source: Global Entrepreneurship Monitor

\section{Nascent entrepreneurship 2002}

The nascent entrepreneurship rate is defined as the number of people that are actively involved in starting a new venture, as a percentage of adult population (18-64 years old). An individual may be considered a nascent entrepreneur if the following three conditions are met: if he has taken action to create a new business in the past year, if he expects to share ownership of the new firm, and if the firm has not yet paid salaries or wages for more than three months (Reynolds et al., 2002, p. 38). Source: Global Entrepreneurship Monitor

\section{New business Formation 2002}

New business activity is measured as the percentage of people in age group of 18 to 64 years who are managing a business less than 42 months old in 2002 (expressed in \%). A firm is defined as a 'new business' if the firm has paid salaries and wages for more than three months but for less than 42 months. Source: Global Entrepreneurship Monitor

\section{Established businesses 2002}

This variable is computed as a percentage of adult population (18-64 years old) with an 'established business'. A firm is defined as an 'established business' if the firm has paid salaries and wages for more than 42 months (Reynolds et al., 2002, p. 38). Source: Global Entrepreneurship Monitor

\section{Total business ownership 2002}

This variable is computed as the sum of 'new businesses' and 'established businesses', both measured as a percentage of adult population (18-64 years old), taken from the GEM 2002 Adult Population Survey. A firm is defined as a 'new business' if the firm has paid salaries and wages for more than three months but for less than 42 months, and as an 'established business' if the firm has paid salaries and wages for more than 42 months (Reynolds et al., 2002, p. 38). The business ownership variable thus measures the stock of incumbent business owners. Source: Global Entrepreneurship Monitor

Independent Variables

\section{Per capita income}

Gross national income per capita 2001 is expressed in purchasing power parities per US\$, and these data are taken from the 2002 World Development Indicators database of the World Bank. We do not use GDP per capita from the GEM database because this variable is measured at exchange rates. We do not want fluctuations in exchange rates to impact the ranking of countries with respect to their level of economic development.

\section{Participation in education (1997).}

We have included gross enrollment ratios in secondary education and tertiary education. Gross enrollment ratios are defined as the total number of students enrolled divided by the total number of people in the appropriate age range. These data are taken from Table 2.12 of the 2001 World Development Indicators database from the World Bank. Source: World Bank

\section{Postmaterialism}

The source of the postmaterialism data are the World Values Survey, 1990-1993 (ICPSR, 1994). Scores for individual respondents are computed on the basis of their rankings of certain items. For the 4-item postmaterialism index, respondents were asked to select the most important and second important goal a country should have from the following four items: a) Maintaining order in the nation, b) Giving people more to say in important government deci- 
sions, c) Fighting rising prices and d) Protecting freedom of speech. The postmaterialism index is constructed as follows:

1= Materialist: first choice item a, second choice item c or first choice item c and second choice item a.

2= Mixed: first choice item a or $c$ and second choice item b or $\mathbf{d}$ or first choice item $b$ or $d$ and second choice item a or c.

3= Postmaterialist: first choice item $b$ and second choice item $d$ or first choice item $d$ and second choice item $b$.

The country scores were aggregates of the individual respondent scores, thus also ranging between 1 and 3 . A similar methodology was used for the 10-item indices, again with an eventual scale ranging between 1 and 3. Source: World Values Survey and European Values Surveys, cumulative data: 1990-1993.

Life Satisfaction

Life satisfaction is also derived from the World Values Survey, 1990-1993 (ICPSR, 1994). The score for this variable is constructed as the average score of the inhabitants of a country rating life as a whole (life satisfaction) on a scale ranging from 1 (completely dissatisfied) to 10 (completely satisfied). Source: World Values Survey and European Values Surveys, cumulative data: 1990-1993 
Table 1: Pearson Product-Moment Correlations among the independent, dependent and control variables ${ }^{1}$

\begin{tabular}{|lllllllllll|}
\hline Variable & 1 & 2 & 3 & 4 & 5 & 6 & 7 & 8 & 9 & 10 \\
\hline 1. Total entrepreneurial activity (\%) & 1.00 & & & & & & & & & \\
2. Nascent entrepreneurship (\%) & $.93^{* *}$ & 1.00 & & & & & & & \\
3. New business Formation (\%) & $.89^{* *}$ & $.66^{* *}$ & 1.00 & & & & & & & \\
4. Established business (\%) & $.56^{* *}$ & .35 & $.70^{* *}$ & 1.00 & & & & & & \\
5. Total business ownership (\%) & $.76^{* *}$ & $.53^{* *}$ & $.90^{* *}$ & $.94^{* *}$ & 1.00 & & & & & \\
6. Per capita income & $-.57^{* *}$ & $-.52^{* *}$ & $-.46^{*}$ & -.22 & -.35 & 1.00 & & & & \\
7. Postmaterialism & $-.45^{*}$ & -.31 & $-.52^{* *}$ & -.28 & $-.41^{*}$ & $.71^{* *}$ & 1.00 & & & \\
8. Life satisfaction & -.04 & -.02 & .01 & .01 & -.00 & $.58^{* *}$ & $.69^{* *}$ & 1.00 & & \\
9. Education-secondary & $-.75^{* *}$ & $-.76^{* *}$ & $-.58^{* *}$ & -.33 & $-.47 *$ & $.75^{* *}$ & $.59^{* *}$ & $.39 *$ & 1.00 & \\
10. Education-tertiary & -.32 & -.31 & -.22 & -.07 & -.15 & $.79 * *$ & $.64^{* *}$ & $.43^{*}$ & $.63 * *$ & 1.00 \\
Mean & 7.99 & 4.73 & 3.64 & 6.15 & 9.78 & 20.12 & 1.91 & 7.26 & 101.33 & 42.70 \\
SD & 4.39 & 2.63 & 2.36 & 3.00 & 4.95 & 9.32 & .20 & .65 & 24.25 & 21.20 \\
\hline
\end{tabular}

* Correlation is significant at the .05 level (two-tailed)

1 Correlations are based on the 27 countries used in the multiple regression analysis. 
Table 2: Regressions on Total Entrepreneurial Activity (TEA) (Nascent Entrepreneurship plus New Business Formation) across 27 Countries

\begin{tabular}{|c|c|c|c|c|c|c|}
\hline Variable & $\begin{array}{l}\text { Postmaterialism } \\
\text { on TEA (H1) } \\
\text { Model } 1 \\
\text { B (t-value) }\end{array}$ & $\begin{array}{l}\text { Postmaterialism and Per } \\
\text { capita income on TEA } \\
\text { (H2) } \\
\text { Model } 2 \\
\text { B (t-value) }\end{array}$ & $\begin{array}{l}\text { Postmaterialism and } \\
\text { Education on TEA (H3) } \\
\text { Model } 3 \\
\text { B (t-value) }\end{array}$ & $\begin{array}{l}\text { Postmaterialism and Life } \\
\text { Satisfaction on TEA (H4) } \\
\text { Model } 4 \\
\text { B (t-value) }\end{array}$ & $\begin{array}{l}\text { All variables on TEA } \\
\text { Model } 5 \\
\text { B (t-value) }\end{array}$ & $\begin{array}{l}\begin{array}{l}\text { All variables plus per } \\
\text { capita income }\end{array} \text { on TEA } \\
\text { Model } 6 \\
\text { B (t-value) }\end{array}$ \\
\hline Postmaterialism & $-9.80(2.55)^{*}$ & $.28(.06)$ & $-3.21(-.84)$ & $-17.46(-3.57)^{* *}$ & $-9.56(-2.73)^{*}$ & $-8.61(-2.33)^{*}$ \\
\hline Per Capita Income & & $-1.21(-3.21)^{* *}$ & & & $-.24(-2.52)^{*}$ & $-.53(-1.52)$ \\
\hline Education-secondary & & & $-.16(-4.92)^{* * *}$ & & $-.12(4.58)^{* * *}$ & $-.11(-3.50)^{* *}$ \\
\hline Education-tertiary & & & .07 (1.71)\# & & $.11(3.32)^{* *}$ & $.12(3.39) * *$ \\
\hline Life Satisfaction & & & & $3.49(2.28) *$ & $4.02(4.36) * * *$ & $3.71(3.73)^{* * *}$ \\
\hline Per capita income-squared & & $.03(2.69)^{*}$ & & & & $.01(.86)$ \\
\hline $\mathrm{R}$ & .45 & .70 & .78 & .59 & .90 & .90 \\
\hline Adj. R2 & .17 & .42 & .56 & .29 & .76 & .76 \\
\hline F-Statistic, df & $6.49^{*}$ & $7.33^{* * *}$ & $12.18^{* * *}$ & $6.40^{* *}$ & $17.58^{* * *}$ & $14.59^{* * *}$ \\
\hline & $(1,25)$ & $(3,23)$ & $(3,23)$ & $(2,24)$ & $(5,21)$ & $(6,20)$ \\
\hline $\begin{array}{l}\Delta \mathrm{R} \text { squared when Postmaterialism } \\
\text { entered last in equation }\end{array}$ & & .00 & .01 & $.35^{* *}$ & $.07 *$ & $.05^{*}$ \\
\hline
\end{tabular}


Table 3: Comparison of Multiple Regressions (using all variable model on (TEA) and other ownership variables across 27 Countries

\begin{tabular}{|l|l|l|l|l|l|}
\hline Variable & $\begin{array}{l}\text { All variables on } \\
\text { TEA } \\
\text { B (t-value) }\end{array}$ & $\begin{array}{l}\text { All variables on \% nas- } \\
\text { cent entrepreneurship } \\
\text { B (t-value) }\end{array}$ & $\begin{array}{l}\text { All variables on new } \\
\text { business formation } \\
\text { B (t-value) }\end{array}$ & $\begin{array}{l}\text { All variables on es- } \\
\text { tablished businesses } \\
\text { B (t-value) }\end{array}$ & $\begin{array}{l}\text { All variables on total } \\
\text { business ownership } \\
\text { B (t-value) }\end{array}$ \\
\hline Postmaterialism & $-9.56(-2.73)^{*}$ & $-1.13(-.45)$ & $-9.77(-4.45)^{* * *}$ & $-.7 .44(-1.59)$ & $-.17 .21(-2.75)^{*}$ \\
Per capita Income & $-.24(-2.52)^{*}$ & $-.11(-1.58)$ & $-.12(-.1 .92) \#$ & $-.07(-.57)$ & $-.19(-1.10)$ \\
Education-secondary & $-.12(-4.58)^{* * *}$ & $-.09(-4.64) * * *$ & $-.04(-2.41) *$ & $-.04(-1.05)$ & $-.08(-1.63)$ \\
Education-tertiary & $.11(3.32)^{* *}$ & $.05(2.02) \#$ & $.07(3.35) * *$ & $.06(1.42)$ & $.13(2.23)^{*}$ \\
Life Satisfaction & $4.02(4.36) * * *$ & $1.67(2.53)^{*}$ & $2.60(4.50) * * *$ & $1.89(1.54)$ & $4.49(2.73)^{*}$ \\
R & .90 & .85 & .86 & .51 & .72 \\
Adj. R2 & .76 & .66 & .67 & .09 & .40 \\
F-Statistic, df & $17.58^{* * *}$ & $10.86 * * *$ & $11.68 * * *$ & 1.50 & $4.45^{* *}$ \\
& $(5,21)$ & $(5,21)$ & $(5,21)$ & $(5,21)$ & $(5,21)$ \\
\hline
\end{tabular}


Table 4: Comparison of Multiple Regressions on Total Entrepreneurial Activity and New Business Formation using Postmaterialism index from different years

\begin{tabular}{|c|c|c|c|c|c|c|}
\hline Variable & $\begin{array}{l}\text { All variables on TEA } \\
\text { using } 1981 \text { data } \\
\text { B (t-value) }\end{array}$ & $\begin{array}{l}\text { All variables on TEA using } \\
1990 \text { data (same as Table 2) } \\
\text { B (t-value) }\end{array}$ & $\begin{array}{l}\text { All variables on TEA using } \\
1995-7 \text { data (4 item) } \\
\text { B (t-value) }\end{array}$ & $\begin{array}{l}\text { All variables on } \\
\text { NBF using } 1981 \text { data } \\
\text { B (t-value) }\end{array}$ & $\begin{array}{l}\text { All variables on NBF using } 1990 \\
\text { data (same as table 3) } \\
\text { B (t-value) }\end{array}$ & $\begin{array}{l}\text { All variables on NBF using } \\
\text { 1995-7 data } \\
\text { B (t-value) }\end{array}$ \\
\hline Postmaterialism & $-5.22(-1.28)$ & $-9.56(-2.73)^{*}$ & $-5.72(-1.72)$ & $-4.26(-1.46)$ & $-9.77(-4.45)^{* * *}$ & $-6.02(-2.60) *$ \\
\hline Per capita Income & $-.37(-2.44) *$ & $-.24(-2.52) *$ & $-.23(-1.77)$ & $-.21(-1.90) \#$ & $-.12(-1.92)$ & $-.10(-1.07)$ \\
\hline Education-secondary & $-.09(-2.24) *$ & $-.12(-4.58)^{* * *}$ & $-.18(-4.59) * * *$ & $-.02(-.58)$ & $-.04(-2.41)^{*}$ & $-.08(-2.77)^{*}$ \\
\hline Education-tertiary & $.09(2.04)$ & $.11(3.32)^{* *}$ & $.15(3.11) * *$ & $.07(2.35) *$ & $.07(3.35)^{* *}$ & $.09(2.68) *$ \\
\hline Life Satisfaction & $3.46(2.56) *$ & $4.02(4.36) * * *$ & $3.90(3.45) * *$ & $1.25(1.30)$ & $2.60(4.50)^{* * *}$ & $2.40(3.05) * *$ \\
\hline $\mathrm{R}$ & .82 & .90 & .89 & .67 & .86 & .81 \\
\hline Adj. R2 & .55 & .76 & .71 & .23 & .67 & .53 \\
\hline F-Statistic, df & $5.47 * *$ & $17.58 * * *$ & $10.48 * * *$ & 2.10 & $11.68^{* * *}$ & $5.31 * *$ \\
\hline & $(5,13)$ & $(5,21)$ & $(5,14)$ & $(5,13)$ & $(5,21)$ & $(5,14)$ \\
\hline $\begin{array}{l}\Delta \mathrm{R} \text { squared when } \\
\text { Postmaterialism en- } \\
\text { tered last in equation }\end{array}$ & .04 & $.07^{*}$ & .04 & .09 & $.25^{* * *}$ & $.17^{*}$ \\
\hline
\end{tabular}

a Similar patterns were found for regressions with a common subset of 20 countries, for 1990 and 1995-7. (Only 10 countries overlap both 1981 and the other time periods and thus all available countries were included for the 1981 period even though some of these countries did not overlap those included during other time periods). 


\section{Publications in the ERIM Report Series Research* in Management}

\section{ERIM Research Program: "Organizing for Performance"}

\section{6}

IPRs, Technological Development, and Economic Development

Wilfred Dolfsma

ERS-2006-004-ORG

http://hdl.handle.net/1765/7301

Institution Building and Change in China

Barbara Krug and Hans Hendrischke

ERS-2006-008-ORG

http://hdl.handle.net/1765/7331

Rational Entrepreneurship in Local China: Exit Plus Voice for Preferential Tax Treatments

Ze Zhu, George W.J. Hendrikse and Barbara Krug

ERS-2006-010-ORG

http://hdl.handle.net/1765/7577

A Process Model of Locational Change in Entrepreneurial Firms: An Evolutionary Perspective Erik Stam

ERS-2006-014-ORG

http://hdl.handle.net/1765/7633

Starting Anew: Entrepreneurial Intentions and Realizations Subsequent to Business Closure Veronique Schutjens and Erik Stam

ERS-2006-015-ORG

$\underline{\text { http://hdl.handle.net/1765/7638 }}$

Agglomeration Economies and Entrepreneurship in the ICT Industry

Frank G. van Oort and Erik Stam

ERS-2006-016-ORG

http://hdl.handle.net/1765/7639

Renascent Entrepreneurship

Erik Stam, David Audretsch and Joris Meijaard

ERS-2006-017-ORG

http://hdl.handle.net/1765/7640

Social Life of Values

Slawomir Magala

ERS-2006-019-ORG

http://hdl.handle.net/1765/7645

Enterprise Ground Zero in China

ERS-2006-024-ORG

Barbara Krug

$\underline{\text { http://hdl.handle.net/1765/7853 }}$

Framing China: Transformation and Institutional Change

ERS-2006-025-ORG

Barbara Krug and Hans Hendrischke

http://hdl.handle.net/1765/7854 
Currents and Sub-currents in the River of Innovations - Explaining Innovativeness using New-Product Announcements Wilfred Dolfsma and Gerben van der Panne

ERS-2006-036-ORG

http://hdl.handle.net/1765/7943

Much Ado About Nothing: A conceptual critique of CSR

J. (Hans) van Oosterhout and Pursey P. M. A. R. Heugens

ERS-2006-040-ORG

http://hdl.handle.net/1765/7894

The Effect of Business Regulations on Nascent and Young Business Entrepreneurship André van Stel, David J. Storey and A. Roy Thurik ERS-2006-052-ORG

http://hdl.handle.net/1765/7996

Postmaterialism Influencing Total Entrepreneurial Activity across Nations Lorraine Uhlaner and A. Roy Thurik ERS-2006-062-ORG

* A complete overview of the ERIM Report Series Research in Management: https://ep.eur.nl/handle/1765/1

ERIM Research Programs:

LIS Business Processes, Logistics and Information Systems

ORG Organizing for Performance

MKT Marketing

F\&A Finance and Accounting

STR Strategy and Entrepreneurship 